ORIGINAL PAPER

DOI: https://doi.org/10.14428/thl.v0i0.1293

\title{
Van Til versus Stroud: Is the Transcendental Argument for Christian Theism Viable?
}

\author{
BÁLINT BÉKEFI \\ Pentecostal Theological College, Budapest \\ Óbuda University \\ balint.bekefi@gmail.com
}

\begin{abstract}
In this paper I introduce the transcendental argument for Christian theism in the context of Reformed theologian and philosopher Cornelius Van Til's thought. I then present the critique proffered by Barry Stroud against ambitious transcendental arguments, and survey various formulations of transcendental arguments in the literature, seeking how the objection bears upon them. I argue that Adrian Bardon's (2005) interpretation is the most helpful in understanding the Stroudian objection. From this interpretation, two types of possible rebuttals are deduced. Proceeding to survey the responses offered by Van Tillians to this objection in the recent literature, I discern two general strategies pursued in these responses, which map onto the previously deduced types of rebuttals: the Biblical justification strategy and the objection-undermining strategy. I argue that all the specific attempts to answer Stroud which I examine here (those of Butler, Bosserman, and Fluhrer) are inadequate and that these two strategies, in general, face serious problems. I conclude with considering the options before the proponent of the transcendental argument for Christian theism and with offering a new objection to the argument, which focuses on its inconsistency with the implications of Christian theism itself.
\end{abstract}

Keywords: Transcendental Arguments, God's Existence, Cornelius Van Til, Reformed Theology, Religious Epistemology

In the introduction I first briefly present Cornelius Van Til's thought and show how a transcendental argument (henceforth: TA) emerges from his apologetics; then I move on to discuss TAs and the Stroudian objection, and end with an analysis of the possible responses and with a formulation of the TA for Christian theism (henceforth: $\mathrm{CT}$; $\mathrm{TACT}^{1}$ ). In the second section I examine the rebuttals to Stroud offered by advocates of TACT along the two possible lines of response delineated in

\footnotetext{
${ }^{1}$ Most of the literature refers to it as TAG (TA for God), but as it seeks to establish the existence of the God of CT specifically, I take TACT to be a more descriptive acronym.
} 
the introduction and argue that none of them succeed. In the concluding section I consider the possibilities before the advocate of TACT and present a new objection against it.

\section{Introduction}

\subsection{Cornelius Van Til}

Cornelius Van Til (1895-1987), a 20 $0^{\text {th }}$-century Reformed theologian and philosopher, was Professor of Apologetics at Westminster Theological Seminary for over four decades. His work has had significant influence in a number of areas (e.g. the socalled Biblical counseling movement and Christian Reconstructionism), but his specialty was philosophy and apologetics, and this is where he himself made the most significant contributions. ${ }^{2}$ Perhaps the best way to understand the outlines of his thought is to survey his main influences - of which, according to most, there are three. (The influence these exerted on him was roughly simultaneous, so the following enumeration is not chronological.)

The first was Princeton Theological Seminary in the 1920's, before its reorganization in 1929 resulting in a so-called "modernist" majority among the faculty. Van Til earned his ThM at Princeton and subsequently served on its faculty for a brief time, before leaving in 1929 with a few of his colleagues to found the theologically conservative Westminster Theological Seminary. Professors at Princeton such as B. B. Warfield ${ }^{3}$ and J. Gresham Machen, coming from a position of confessional Reformed theology, insisted on the objective truth and verifiability of Christianity and developed an apologetic system on this basis which sought to be undergirded by evidential support. "Old Princeton stood upon Calvin's doctrines of natural revelation and man's innate sense of deity, as they constructed a robust apologetic for the Christian Faith." (Bosserman 2014, 1-2)

His second influence was Dutch Neo-Calvinism, through his (Dutch) familial background and his education at Calvin College under Professor of Philosophy W. H. Jellema. Dutch Reformed thinkers such as Herman Bavinck and Abraham Kuyper placed significant emphasis on the notion of antithesis: the idea that due to the sinfulness of humankind, Christian and non-Christian thought do not share any common or neutral "ground" 4 from which persuasive apologetic argumentation

${ }^{2}$ The two classical analyses of Van Til's thought are Frame (1995) and Bahnsen (1998); a more recent one which has recently been becoming somewhat influential is Bosserman (2014); two other recent, more accessible and concise treatments can be found in Frame (2015a, 529-37) and Morley (2015, 49-89). My presentation is primarily based on the last three.

${ }^{3}$ Although Warfield died in 1921, his thought and writings remained influential for decades.

${ }^{4}$ I am well aware of the distinction between common ground and neutral ground; neo-Calvinism, however, arguably eschews both neutral ground and common notions, that is, common ground on the level of thought, while it may endorse common (though not neutral) ground on the level of metaphysics or anthropology, which would mean that the common ground between the Christian and the non-Christian is that both are created in the image of God. 
could proceed. "Amsterdam, on the other hand, emphasized Calvin's doctrine of total depravity, and developed the view that unregenerate reasoning must be antithetical to Christian thinking at virtually every point, with the result that it is largely futile to attempt to develop a Christian apologetic." (Bosserman 2014, 2)

The third major influence on Van Til's thought, which has sometimes been neglected and sometimes exaggerated, is Absolute Idealism. (McConnel 2005; Morley $2015,63)$ This came again through his professor W. H. Jellema at Calvin College, and through courses with A. A. Bowman at Princeton University, where Van Til earned his PhD. While he was critical and careful in his appropriation of Idealist thought, many of his phrases and formulations have their root in it (in such a way which he regarded as compatible with his theology). Idealism's most relevant ideas are aptly summarized by Bosserman:

\begin{abstract}
British-American idealism championed the Hegelian doctrine that a single all-encompassing system, dubbed the "Absolute" is the precondition of all rational discourse. On their view, even those philosophers who doubt, deny, or fall short of a vision of the Absolute, can be proven to unwittingly rely upon it. In this way, opposing philosophies are disproven by way of a "transcendental" argument to the effect that they presuppose the sort of allencompassing rational system which they claim to deny. (Bosserman 2014, 2)
\end{abstract}

When one tries to combine these three strands of thought under the critical control of Reformed theology, the principles of Van Til's apologetics emerge. First, with Old Princeton, Van Til affirms that the truth of CT really can be established through rational proof, while he argues that evidential arguments based on Common Sense Realism presupposed by the Princeton apologists cannot deliver the certainty which CT asserts. Second, with Neo-Calvinism, Van Til affirms that there is no common ground of thought upon which the Christian and the non-Christian can both consistently agree, but argues that CT can be proven-therefore the defense of CT cannot be direct; rather it must be indirect. Arguing indirectly for CT means providing an argument for CT from the impossibility of the contrary-the exact meaning of which can be understood via the next point.

Third, with both Neo-Calvinism and Absolute Idealism, Van Til affirms that we are not adjudicating between isolated propositions, but between entire, mutually exclusive systems of thought and life or Weltanschauungen-and the basis of this adjudication is the systems' capability to account for human experience. By showing that non-Christian thought cannot account for basic elements of rational experience and thought, such as predication, language, or logic, the impossibility of the Christian system's meaningful and consistent denial establishes indirectly the necessity of CT for human rationality. This is what Van Til variously called arguing by implication, by presupposition, indirectly, from the impossibility of the contrary, or transcendentally. (Butler 2002, 73-76; Anderson 2005, 57-60; Bosserman 2014, 91-97; 
Morley 2015, 68-81) 5 TACT is thus an argument for CT which seeks to establish CT as the necessary precondition of intelligible experience through demonstrating that its negation undermines or cannot account for this intelligibility, and is therefore selfdefeating.

However, one phrase needs to be clarified: what do we-and what did Van Tilexactly mean by CT? Which proposition cannot be denied on the pain of self-defeat? He insisted that since CT and its denial constitute antithetical worldviews, it is both inappropriate and impossible to prove isolated tenets of CT to the non-Christian one by one, building on the previously established ones (an approach he disapprovingly called "blockhouse methodology"). Moreover, he argued that the various doctrines of which CT consists somehow depend on one another:

\begin{abstract}
A truly Protestant method of reasoning involves a stress upon the fact that the meaning of every aspect or part of Christian theism depends upon Christian theism as a unit. When Protestants speak of the resurrection of Christ they speak of the resurrection of him who is the Son of God, the eternal Word through whom the world was made. The truth of theism is involved in this claim that Christians make with respect to the domain of history. And what is true of the resurrection of Christ is true with respect to all the propositions about historical fact that are made in Scripture. No proposition about historical fact is presented for what it really is till it is presented as a part of the system of Christian theism that is contained in Scripture. To say this is involved in the consideration that all facts of the created universe are what they are by virtue of the plan of God with respect to them. Any fact in any realm confronted by man is what it is as revelational through and through of the God and of the Christ of Christian theism. (Van Til 2008, 136, emphasis mine)
\end{abstract}

As he writes both explicitly and through a few examples, for Van Til, CT can only be presented in a form which preserves the interrelated nature of its parts, because "the meaning of every aspect or part of Christian theism depends upon Christian theism as a unit". However, this does not exactly mean that every single proposition contained in or entailed by CT has to be established transcendentally: "If we are to defend Christian theism as a unit, it must be shown that its parts are really related to one another." (Van Til 2003, 19) The significance of this is that, as Bosserman explains, Van Til understood the major doctrines of CT (taken in a confessional Reformed sense) to imply one another. ${ }^{6}$ (Bosserman 2014, 139-48)

What are, then, the main concepts or theses which Van Til and his disciples take to be foundational to CT? Summarizing the literature, they are roughly the following: in metaphysics, the Trinity, the incarnation of the Son, and the distinct but dependent

\footnotetext{
${ }^{5}$ Riley's extended, careful, and wide-ranging discussion is also worth commending: Riley (2014, 67-154).

${ }^{6}$ A more detailed set of arguments for these implications is laid out in the last part of Bosserman's study. (Bosserman 2014, 175-248)
} 
realm of creation; in epistemology, the Scriptures as divine revelation warranted by the testimony of the Holy Spirit, and the entire creation as revelatory; and in anthropology, humans as fallen (physical and spiritual) beings created in the image of God. (Butler 2002, 122-23; Tipton 2004, 93-94; Bosserman 2014, 91-97; Baird 2015; Oliphint 2015) For Van Til, if one were to deny any of these, one would end up with a worldview which is unable to "account for" or ground the most fundamental experiences of human mental life.

It should be noted that some recent interpreters of Van Til emphasize other streams of thought as highly influential in Van Til's views, namely the biblical theology of Geerhardus Vos on the one hand (Baird 2015; Dennison 2015; Fluhrer 2015, 168-83), and the dogmatics of Reformed scholasticism on the other (Van Asselt 2002; Oliphint 2015; Sutanto 2016). An overlapping set of scholars also doubt that Van Til really endorsed a "formal" argument like TACT, and claim that philosophical proof is alien to the Reformed thought which Van Til represents. ${ }^{7}$ (Tipton 2004, 170; Shannon 2012, 324: n. 4; cf. Oliphint 2013, 87-122; 2016) If they are right, then TACT as discussed in this paper ought not to be attributed to Van Til himself, but rather to some of his self-described disciples.

\subsection{Transcendental Arguments}

TAs have their origin in Immanuel Kant's "The Critique of Pure Reason" and were reintroduced into analytic philosophical discussions primarily through the work of P. F. Strawson and Barry Stroud. ${ }^{8}$ While there is significant disagreement concerning their exact nature, James Skidmore aptly summarizes their basic point:

Transcendental arguments are diverse, but they share a particular strategy
in attempting to overcome the skeptic. The goal is to locate something that
the skeptic must presuppose in order for her challenge to be meaningful,
then to show that from this presupposition it follows that the skeptic's
challenge can be dismissed. In short, the aim is to show that if the skeptic's
challenge makes sense, what she doubts must in fact be true. (Skidmore
2002, 121)

TAs are thus primarily anti-skeptical arguments which seek to show that the skeptic's very ability to formulate the skeptical challenge relies on or presupposes something which the skeptic intends to doubt. While this general description is mostly agreed upon by philosophers working in the field, consensus pertaining to

\footnotetext{
7 Riley argues against this view in the fourth chapter of his dissertation: "Van Til's Transcendental Argument: Proof or Persuasion." (Riley 2014, 111-54) Judging this debate is beyond the scope of the present paper. Another influential and sympathetic analysis of Van Til's thought which ends up not committing itself to TACT can be found in Frame (1995); cf. Frame (2015b).

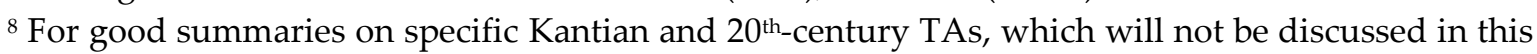
paper, see Förster (1989, 3-14) and Butler (2002, 90-103).
} 
further details proves elusive-so in what follows I shall briefly survey four views on the form TAs take: the "no specific form" view, the modal view, the presupposition view, and the self-defeat view. These views will be evaluated according to two considerations: first, whether they convey the general characteristics of TAs described above; and second, whether the most prominent critique of TAs, that of Barry Stroud (1968), can be interpreted on their terms. ${ }^{9}$ In order to do this, let us first introduce the Stroudian critique.

Stroud in his influential paper "Transcendental Arguments" analyzes two TAs proposed by Strawson and Shoemaker. After criticizing both of them for assuming what he takes to be unstated verificationist premises, he explores what TAs generally seek to show. He defines a "privileged class" of propositions, where "for any proposition $S$ that is a member of the privileged class, the truth of $S$ follows from the fact that somebody asserted it, or denied it, or said anything at all". (Stroud 1968, 253) The significance of this class lies in its potential to answer the skeptic:

The existence of the privileged class is obviously important, since if it could be proved that those propositions which the skeptic claims can never be adequately justified on the basis of experience are themselves members, then from the fact that what the skeptic says makes sense it would follow that those propositions are true. (Stroud $1968,254)$

For Stroud, this is what TAs seek to show. After arguing that the two specific attempts mentioned above do not succeed, he registers his pessimism with regard to the general project. It is here that he formulates the Stroudian objection to TAs: for propositions doubted by the skeptic, it is doubtful if their membership in the privileged class can be demonstrated, since

for any candidate $S$, proposed as a member of the privileged class, the skeptic can always very plausibly insist that it is enough to make language possible if we believe that $S$ is true, or if it looks for all the world as if it is, but that $S$ needn't actually be true. (Stroud 1968, 255, emphasis original)

While Stroud did not give a closely argued demonstration for the general truth of this observation, other analyses of various TAs lend additional support to his critique. (Thomson 1964; Rorty 1971; Brueckner 1983) Bluntly put, his question is this: "Why should one think that what one must believe or cannot deny is actually true?" For Stroud, the only reason would be if one subscribes to verificationism, but

\footnotetext{
${ }_{9}^{9}$ This last phrase just means that if Stroud's critique is significant, as most students of TAs think and as this paper presupposes, it should be possible to show how it bears on TAs in general, and the most promising way to criticize a type of argument in general is to point out a problem with its form.
} 
subscribing to that would render TAs superfluous. (Stroud 1968, 256) This critique gave rise to a distinction between two types of TAs: modest TAs, which only seek to prove that some proposition must be believed for language or meaning or intelligibility, and ambitious TAs, which argue that a proposition must be true for these undeniable experiences to hold. Seeing the difficulty of developing a sound ambitious TA, many have come to believe that formulating such arguments is likely impossible. (Stern 2017)

Having presented the Stroudian objection to TAs, we shall move on to exploring four views enumerated above regarding the form of TAs, the first of which is what I called the "no specific form" view. For A. C. Grayling, for example, "TAs are nothing special in virtue of their form, being distinctive only in virtue of their content and aims." (Grayling 1985, 95) As he writes earlier, "This indeed is Strawson's view; that there is nothing distinctive about the form of TAs, and that what is distinctive about them is their aim and subject-matter." (94) According to Grayling, what makes TAs unique is exclusively their aims and content, not their form. This is appealing in that the various TAs offered in the literature do not obviously share a common structure; however, it provides no help in seeing the general point of Stroud's objection.

Second, the modal view, perhaps most prominently represented by Robert Stern, claims that TAs "involve a claim of a distinctive form: namely, that one thing $(X)$ is a necessary condition for the possibility of something else (Y), so that (it is said) the latter cannot obtain without the former." (Stern 2003, 3) While Stern notes that some further properties characterize TAs, mostly regarding the content of " $X$ " and " $Y$ ", nevertheless when it comes to their form, the following seems to be an accurate depiction thereof:
(M1) If possibly, $p$, then necessarily, $q \cdot \cdot^{10}$
(M2) Possibly, $p$.
(M3) Therefore, necessarily, $q$.

In the context of TACT, James N. Anderson and David Reiter have done some additional work on the modal structure of TAs (Anderson 2011; Reiter 2011), and have come to slightly different conclusions than Stern; however, this need not detain us here except for one observation, since my comments on the modal form of TAs mostly apply to their formulations as well. This one observation is Anderson's recognition that the necessity expressed in (M1) and (M3) "is a relative necessity: it is a necessity indexed to human thought or experience". ${ }^{11}$ (Anderson 2011, 193, emphasis

10 Some might prefer to replace (M1) with its contrapositive:

$\left(\mathrm{M} 1^{*}\right)$ If not necessarily, $q$, then not possibly, $p$.

Additionally, one might (more plausibly) take the necessity to pertain not to $q$, but to the implication - see Anderson (2011) and Reiter (2011) on these details of the modal view.

11 One might consider Oliphint's interpretation of James F. Ross's understanding of God as the creator of possibilia, arguing that all possibilities must be indexed to actual entities in order to have 
original) Defining this transcendental necessity he writes that "a state of affairs $S$ is transcendentally necessary just in case $S$ obtains in the actual world and every other possible world in which there is human thought or experience." (Ibid., emphasis original)

The reason Anderson's definition is significant is that this understanding of necessity helps one express the unique features of TAs through their form-a virtue Stern's approach of identifying this necessity with metaphysical necessity lacks. However, one can still hardly find a direct application of Stroud's critique to this interpretation. The reason, I believe, is that some other crucial features of TAs are still not incorporated into it: the indirect way in which they seek to demonstrate that something is a precondition of experience and the self-defeating nature of the precondition's denial.

The third view which sees the defining feature of TAs in the notion of presupposition was proposed by Don Collett in an attempt to formalize Cornelius Van Til's understanding of TACT. (Collett 2009) Collett noted Van Til's claims that TACT is neither an entirely deductive nor an entirely inductive argument, and that the truth of CT is a precondition of all predication, including that of the denial of CT. Seeing it as a concept which well represents these considerations, he sought to formulate an argument based on Bas van Fraassen's appropriation of P. F. Strawson's interpretation of semantic presupposition. ${ }^{12}$ (van Fraassen 1968) On this understanding, if $p$ presupposes $q$, then if $q$ is false, then $p$ is neither true nor false, but rather meaningless. Therefore both the truth and the falsehood of $p$ necessitate the truth of $q$. A presuppositional TA would then take the following form:

(P1) $p$ presupposes $q$.

(P2) $p$ or not $p$.

(P3) Therefore, $q$.

While I suspect that there are several problems with this analysis (cf. Frame 2015b, 75-78), I shall present only one which I take to be sufficient to render the presupposition view unhelpful. The fact that in this form the non-existence of intelligible experience necessitates the truth of CT shows that it is not a faithful representation of TAs, which do not claim that the given precondition would hold even if there were no such experience. It seems to me that not even Collett would

meaning at all. On this basis it could perhaps be argued that we cannot even talk about possible worlds which lack intelligible experience; thus metaphysical necessity collapses into transcendental necessity. (Oliphint 2011, 238-41) As Oliphint puts it, the "content and context" of possibility "must have its genesis in the actual"; "it might be the case that bare possibility is, in fact, nothing at all." (239, emphasis removed)

12 This is notable because several scholars of Van Til have come to appreciate Collett's interpretation as something close to what Van Til originally had in mind. (Tipton 2004, 143: n. 360; Reiter 2011, 3-5; Shannon 2012, 324: n. 4; Bosserman 2014, 95: n. 31; Oliphint, quoted in Fluhrer 2015, 150: n. 336) 
want to affirm that the non-existence of intelligibility necessitates the truth of CT, but rather the possibility of the meaningful affirmation thereof does. (Collett 2009, 33: n. 70) That clarification, however, betrays a different argument structure:

(P1') The possibility of meaningfully affirming or denying $p$ implies

$q$.

(P2') It is possible to meaningfully affirm or deny $p$.

(P3') Therefore, $q$.

This form - an ordinary modus ponens - presents a legitimate structure for exploring the preconditions of meaning, but it is too narrow to include all TAs, some of which address not meaning, but causality or perception, for example. Nor does it help in understanding the Stroudian objection or seeing how (P1') is to be established.

Last comes in our enumeration the self-defeat view as expressed most prominently by Adrian Bardon. (Bardon 2005) He points out that many TAs can be taken to argue for a proposition through showing that the denial of said proposition entangles the skeptic in a performative inconsistency, as in Descartes's cogito: how could one affirm one does not exist, unless one did in fact exist? The cause of this inconsistency is the self-defeating nature of the given proposition's denial. (Bardon 2005, 72-74, 84-87) Accordingly, such a TA for a proposition $p$ would take the following form:

(S1) If the negation of $p$ is self-defeating, then $p$ is true.

(S2) The negation of $p$ is self-defeating.

(S3) Therefore, $p$ is true.

The appeal of this structure comes from its capturing an essential feature of TAs about the way they seek to establish that some $p$ is a necessary precondition of intelligible experience: through showing that their negation cannot be affirmed truly or rationally. ${ }^{13}$ However, to regard it an acceptable formulation, we should be able to see how the Stroudian objection bears on it. In order to do this, we have to introduce a distinction that Bardon makes between two kinds of self-defeat:

In short, if a performatively self-falsifying proposition is affirmable, it is not true; if a self-stultifying proposition is true, it is not rationally defensible. It is inconsistent to affirm a self-stultifying proposition because that one is justified in making a claim is a pragmatic implication of making that claim. This inconsistency is not performative, however: sincerely affirming such a proposition means only that one is implicitly committed to its being false, not that it is. The very fact of the performance of the proposition-as

${ }^{13}$ I suspect that for a fully proper formulation one would have to combine the modal and the selfdefeat views; however, most or all of what I will say on the basis of the self-defeat view would apply to that combination as well. 
opposed to the content of the proposition itself-says nothing about whether it is justified. (Bardon 2005, 74-75)

A proposition then is performatively self-falsifying if its affirmation implies its falsehood; it is self-stultifying if its truth implies that one can never be rationally justified $^{14}$ in affirming it. If we apply this distinction to the form presented in (S1)(S3), the following premises emerge, which I will take as my final formulation of TAs in general:

(1) If the negation of $p$ is either self-stultifying or performatively self-

falsifying, then $p$ is true.

(2) The negation of $p$ is either self-stultifying or performatively self-

falsifying.

(3) Therefore, $p$ is true.

Stroud's objection is that showing that we must believe something (probably because we can never be justified in believing its negation) does not establish its truth. We can plausibly take Stroud to be talking about self-stultification - and so the gist of his critique, the Stroudian thesis, can be formulated in the following way:

(ST): Self-stultification does not imply falsehood.

Maybe the proponent of a TA does not know ST, but for all he knows, it is quite possible that ST is the case (for most propositions, at any rate), and-especially given the anti-skeptical nature of TAs - it is clear that the burden of proof is on him to argue against it; otherwise he cannot hold to premise (1) as a premise in an antiskeptical argument. Given this thesis, premise (1) has to be modified in order to preserve its (knowable) truth:

$\left(1^{\prime}\right)$ If the negation of $p$ is performatively self-falsifying, then $p$ is true.

The argument from premises (1'), (2), and (3) is, however, invalid, since premise (2) allows the negation of $p$ to be merely self-stultifying, which does not imply $p$ according to $\left(1^{\prime}\right)$. There are two ways in principle to make this argument valid. The first is what could be called strengthening the second premise, i.e. substituting ( 2 ') for (2):

$\left(2^{\prime}\right)$ The negation of proposition $p$ is performatively self-falsifying.

${ }^{14}$ I use the phrases "justification" and "warrant" (and their derivatives) interchangeably in this paper so as not to commit myself to any specific view on epistemology. By either "justification" or "warrant" I mean that which is needed for a true belief to possess the status of knowledge. 


\section{BÁLINT BÉKEFI}

The reason one could see this as strengthening premise (2) is that it seeks to meet narrower, stricter conditions with regard to the negation of the proposition. In a similar manner, the other strategy to make the argument valid is weakening the first premise through preserving the broader conditions of the original premise (1). In order to achieve this, the proponent of this second possible way has to show that (ST) is false. This approach could be called the objection-undermining strategy.

The plausibility of this analysis of the Stroudian objection is further supported if we consider the situation which emerged from Stroud's critique: one has to subscribe either to verificationism or to idealism to avoid the objection. (Stroud 1968, 255-56; Brueckner 1996, 267; Stern 2007, 146) We can see that the reason is that both of these views deny ST. For verificationism, truth implies knowability; and since selfstultification implies unknowability, it implies falsehood. For idealism, all truth is known, therefore all truth is knowable; and since self-stultifying propositions are not knowable, they are false-so ST is false. Here we can see that, for Stroud, the weakening of the first premise is the main possibility for preserving ambitious transcendental arguments-however, he thinks that this is only possible if one is willing to accept highly implausible philosophical positions. ${ }^{15}$

To conclude our discussion of TAs and the introductory section in general, let us formulate TACT according to the modified self-defeat view:

(C1) If the negation of CT is either self-stultifying or performatively self-falsifying, then CT is true.

(C2) The negation of CT is either self-stultifying or performatively self-falsifying.

(C3) Therefore, CT is true.

Where the stronger first and second premises are, respectively:

(C1') If the negation of CT is performatively self-falsifying, then CT is true.

(C2') The negation of CT is performatively self-falsifying.

\section{Evaluating the responses}

\subsection{Strengthening the second premise: the Biblical justification strategy}

First, Michael R. Butler, in his excellent essay on TACT, after admitting to the difficulty of the challenge, explains that

\footnotetext{
${ }^{15}$ While Stroud does not note this here, others have pointed out - though not in this explicit waythat the first strategy of strengthening the second premise might be a viable option in some cases. (Cassam 2003; Bradford 2004; Bardon 2005; Riley 2014, 167-77) This is further confirmation of the above analysis.
} 
the Christian worldview is not a mere conceptual scheme. It claims to do more than simply provide us with the necessary preconditions of experience. The Christian worldview posits a sovereign, creator God who is both personal and absolute in His nature. This God is, moreover, a speaking God who reveals truths to us about Himself and the world. In His revelation to us He declares that $\mathrm{He}$ has made a world and that this world exists independently from Himself and us. On the basis of His revelation, therefore, which is itself the necessary precondition of experience, we can know truths about the world and God. (Butler 2002, 123)

Now, while this could sound initially appealing, it is difficult to see how Butler's response aims to answer Stroud. The fact that the Christian worldview "posits" a God and various doctrines related to him does in no clear way contradict the idea that it is "a mere conceptual scheme" in its relevant aspects (i.e. being a set of propositions), which is being argued against. Moreover, this response seems to be circular, as Sims explains: "However, Butler seems to assume the very thing he asserts, namely the metaphysical truthfulness of the Christian worldview based on God's existence." (Sims 2006, 56: n. 88) Riley explains the problems with Butler's solution in greater detail:

Indeed, I think that Butler's suggestion not only fails to answer Stroud's dilemma: it may in fact exacerbate the problem. To increase the richness of the world-directedness of one's transcendental argument, as Butler clearly seems to suggest, hardly seems an advisable move when the very possibility of any kind of world-directed argument is precisely what is at issue. It seems that Stroud's response here would remain unchanged: no matter how rich the conception of the worldview that one finds necessary by transcendental argument, it is always possible to insist that we merely must believe that a sovereign, personal, absolute, Creator God exists, that he has created a world that he says is independent of him and of us. (Riley 2014, 22)

So, it appears rather clearly to be the case that on our initial attempt to understand and apply Butler's rebuttal, it fails in a surprisingly straightforward way. However, it is possible to interpret his comments in a different sense, where the question concerns the justification of premise (C2'); Butler may be suggesting that the justification for believing premise $\left(\mathrm{C}^{\prime}\right)$ comes through divine special revelation. ${ }^{16} \mathrm{I}$ shall call this the Biblical justification strategy. What might motivate a proponent of the argument to take this approach? I see three main reasons.

\footnotetext{
${ }^{16}$ Note that Butler does not specifically identify the proposition or premise which he believes we can know by way of revelation, but we can at least use his comments as a springboard to explore this possibility, especially given my impression-based on informal discussions - that many Van Tillians are attracted to this option. If we were to take the Biblical justification strategy as arguing for (C1) as warranted by revelation, most or all objections presented here would apply.
} 
First, Christian epistemological considerations. As Butler notes above, Christianity, at least in its confessional Reformed form espoused by Van Til and most of his disciples, has some distinct elements to its epistemology. As Louis Berkhof says, "The principium cognoscendi externum is God's special revelation. The knowledge which God desires that we should have of Him is conveyed to us by means of the revelation that is now embraced in Scripture." (Berkhof 1996, 96) According to this sort of Reformed theology, one's primary source of theological truths ought to be the Holy Scriptures, that is, the Bible (understood to contain the books of the Protestant canon). On what basis then should one accept the Scriptures as authoritative? Berkhof argues that this principium cognoscendi internum, the principle for knowledge that is internal to the human knower is "faith", which in turn is to be properly grounded in the testimonium Spiritus Sancti, the testimony of the Holy Spirit. (Berkhof 1996, 97, 182-86; cf. Oliphint 2015, 449-53) These doctrines may encourage the apologist who wishes to integrate his philosophy with his theology to seek justification for his premises in divine revelation.

Second, Van Tillian apologetical principles. According to Van Til and his disciples, humans as autonomous knowers are limited both by their finiteness and by the effects sin has had on their cognitive faculties. (Riley 2014, 269) What is more, according to this theology, non-Christians are strongly disposed not to accept the truth of CT. Therefore it is both improper and inevitably unsuccessful to seek to establish the existence of God through means which take the individual person as their "starting point," proceed through logical deduction and purportedly conclude that CT is true. As Greg Bahnsen, one of Van Til's foremost disciples puts it in his apologetics textbook for Christians:

[I]t should be clear that our defense must be rooted in the presupposed word of God rather than guided by clever arguments which rest in assumed intellectual autonomy. We ought not in our apologetic teach the unbeliever to trust himself in order to (savingly) rely wholly on the Lord! (Bahnsen 2011, 76, emphasis original)

Third, the nature of TAs. Stroud remarked in an answer to Jay Rosenberg's critique of the transcendental project that arguments of this sort in some sense presuppose the truth of their conclusion. That is, if the truth of a proposition $S$ indeed has to obtain so that one can have meaningful experience, then all rational discourse, including transcendental argumentation, has to assume $S .{ }^{17}$ Stroud puts it in the following way:

If there are certain ways in which we must think if thought and experience are to be possible at all, it will not be surprising to find that we can only think about those ways of thinking only from 'within' them. We could

\footnotetext{
17 Riley concludes his dissertation with arguing that this is one of the most important points one has to recognize in order to succeed in presenting a sound formulation of TACT. (Riley 2014, 285-86)
} 
stand 'outside' them only by violating the very conditions that make thought possible. So if we also manage to 'legitimize' those ways of thinking we will have to do so 'from within' as well. (Stroud 1977, 106)

A Van Tillian can then reason the following way: since TACT argues for the entirety of CT as that which is indispensable for intelligent experience, and since-as Stroud says - one can argue for transcendentally necessary positions only "from 'within'" them, the proponent of TACT should consider what a reliable way of knowing is within CT. He can then conclude that premise (C2') should be established through divine revelation; that is, through the interpretation of the Bible and through theological considerations derived from that interpretation. This, he could argue, is an epistemologically reliable method "within" CT-thus if the premise is demonstrated this way, nothing more is left to be legitimately desired. ${ }^{18}$

Does this approach adequately answer Stroud's critique? In one sense it may, since it claims to secure justification for the strong premise ( $\left.\mathrm{C}^{\prime}\right)$. I believe, however, that the costs are devastating. I see two crucial problems with this solution: first, superfluity; and second, an inadequate epistemology. Let us turn to them in order. First, let us elaborate on the Biblical justification argument for (C2'), which could be put in the following form:

(4) Whatever the Bible affirms is true. (premise)

(5) The Bible affirms (C2'). (premise)

From (4) and (5), (C2') follows. In this discussion, we will grant (5). However, one can find a major fault with this argument. Accepting (4) is tantamount to accepting $\mathrm{CT}$, especially on a confessional Reformed understanding thereof, characteristic of Van Til and his disciples, who espouse the claim that "the Bible affirms CT," or maybe that "CT is the sum of what the Bible affirms." (Van Til 2008, 127) On this definition of CT the conclusion (C3) follows from premise (4) without utilizing the transcendental argumentation found in $\left(\mathrm{C1}^{\prime}\right)$ and $\left(\mathrm{C2}^{\prime}\right)$, rendering it superfluous. This is the first problem.

To see the second serious fault with this approach, one has to examine the epistemological considerations necessary for justified belief in (4). Thomas M. Crisp in his article "On Believing that the Scriptures are Divinely Inspired" (T. M. Crisp 2009) observes that there are three main approaches taken by those who seek to

\footnotetext{
18 Many proponents of Van Til's so-called "presuppositionalist" apologetic admit to engaging in some kind of circular reasoning, which kind, they maintain, is not fallacious (Bahnsen 2011, 63; Frame $2015 b, 10)$, though Frame notes that he has lately become more reluctant to accept the label of "circularity". (2015b, 11: n. 19) See also K. Scott Oliphint's analysis of the relationship between the Reformed principia cognoscendi and circular reasoning, including his discussion of the views of earlier Reformed theologians (Gisbertus Voetius and John Owen) on circular argumentation based on Scripture. (Oliphint 2015, 449-53)
} 
justify this belief. ${ }^{19}$ The first is that of Locke and Richard Swinburne, which seeks to assess the available evidence and arrives through probability calculus to the conclusion that (4) or something in its neighborhood is highly probable. The second consists of an appeal to an external, supposedly authoritative testimony - that of the Church or experts in relevant fields. (T. M. Crisp 2009, 189-90, 201-4, 207-12) These two, however, are not available to the proponent of TACT, since they rely on perceptual knowledge, and therefore beg the question against the skeptic.

The third and final approach appeals to what I earlier identified as a potential motivation for the Biblical justification strategy, that is, the peculiar features of a Christian epistemology. As presented earlier, Reformed theologians argue that the Holy Spirit imparts faith to believers, where "faith" plausibly includes justification for the given belief. A contemporary epistemological model incorporating these notions can be found in the writings of Alvin Plantinga, where the so-called inner instigation of the Holy Spirit (IIHS) is to be understood as a belief-forming cognitive process which, when functioning properly in the appropriate environment, yields true, properly basic beliefs possessing sufficient warrant to be considered knowledge. ${ }^{20}$ Could a proponent of TACT appeal to IIHS in order to support the claim that (4) is justified or warranted? I say no, for one major reason.

The problem is that Reformed epistemology cripples the Biblical justification strategy so that it voids TACT of all persuasive power. The crucial fault with the utilization of the Plantingan model here is that the IIHS produces beliefs only in the minds of Christian believers. ${ }^{21}$ Christians, in turn, believe at least the main points of CT-so the argument's crucial premise is only warranted for those who mostly accept its conclusion. The problem would apparently stay were one to construct an internalist account of justification for (4) - it is hard to see how that account would not need the knower to believe notions unique to $\mathrm{CT}$ in order to justify the premise. But then it would again be justified only for those who already believe the gist of the conclusion. The argument could thus not aspire to convince the skeptic, which one would expect a TA to do. For all these reasons then, I consider the Biblical justification strategy untenable.

\footnotetext{
${ }^{19}$ One might object that my premise (4) and what Crisp calls his "Main Question" are not identical, the former being "whatever the Bible affirms is true," and the latter stating that "the Bible is divinely inspired" (T. M. Crisp 2009, 189). Note, however, that on the confessional Reformed view these two propositions mutually imply one another-since the Bible affirms that it is divinely inspired, and divine inspiration entails (again, on the confessional Reformed understanding) complete truthfulness, or inerrancy.

${ }_{20}$ Curiously, Plantinga does not believe that the "faith" supported by IIHS includes premise (4) in our argument (Plantinga 2000, 248: n. 307). Here he departs from the historic Reformed confessions, including the Belgic Confession (V.) and the Westminster Confession of Faith (I. 5.), which he himself admits. (Plantinga 2000, 248: n. 308) I am not persuaded to follow him in his attenuation of this definition.

21 So teaches the Reformed tradition as well, and not only that-Plantinga, for example, cites Thomas Aquinas as an early representative of this position. (Plantinga 2000, 249)
} 


\title{
2.2. Weakening the first premise: the objection-undermining strategy
}

Two recent attempts at responding to the Stroudian critique of TACT can be best understood as instances of the objection-undermining strategy as defined in the introduction of this paper. First, B. A. Bosserman in his recent study anticipates an objection to his formulation of TACT which seems to be close to what Stroud offers. I quote his comments in their entirety:

\begin{abstract}
Another objection to Van Til's presuppositionalism is that it is covertly pragmatic. Far from making any headway toward demonstrating that Christianity is objectively true, Van Til has really only proven that Christianity represents a most, or even the most useful and desirable belief system. Yet, again, the objector has lapsed back into the very sort of position that Van Til has proven untenable. If reality were the sort of place where subjective and objective truth could be so disconnected, the objector would have no ground for supposing that his reasoning process advances by objectively valid inferences. Hence, the objection that Van Til's proof is merely pragmatic, rather than both useful and true is itself incoherent, until and unless the objector can prove that reality is, or even could be, marked by such a dichotomy. (Bosserman 2014, 105-6, emphasis original)
\end{abstract}

It is somewhat difficult to see through the gist of Bosserman's point. In what follows, I will substitute conceptual necessity (that something must be believed) for "usefulness" and "pragmatism," since that's what Bosserman seems to be thinking of. ${ }^{22}$ Accordingly, Bosserman takes the objection to be that TACT only establishes the conceptual necessity of CT, but does not prove that it is true-which is a good understanding of the Stroudian objection.

His rejoinder is that the objection itself commits the objector to a position according to which conceptual necessity is not related to truth. He points out that this position warrants skepticism on the side of the objector, which, however, precludes him (the objector) from employing his conceptual procedures to arrive at truth - truth concerning, among other things, the validity of TACT. He appears to argue that the objection entails a distinction between the "most desirable belief system" and truth, or "subjective" and "objective" truth. Bosserman further maintains that this distinction is "untenable" and "incoherent" in that, if it is true, it precludes the objector from rationally believing that it - or nearly anything else-is. Hence, he seems to claim that ST is self-stultifying.

Now, it is not at all obvious what one should make of this idea. ${ }^{23}$ Bosserman argues that it leaves its proponent with "no ground" for trusting in beliefs arrived

${ }^{22}$ Bosserman's footnote at the end of this passage citing the relevant portions of Butler's 2002 essay further substantiates this interpretation.

${ }^{23}$ It appears that this situation is not conceivable, since conceiving constitutes intelligible experience, thereby committing one to one's transcendentally necessary beliefs. It would hence involve one's conceiving that $S$ is false on the basis of believing that $S$ is true, which seems rather contradictory. 
upon through logical inferences, making it "incoherent". On the other hand, Stroud maintains that rejecting ST brings one to a dilemma, one horn of which commits one to a metaphysical position which is widely considered untenable (idealism), the other of which renders TAs superfluous.

It seems to be true that, as Bosserman points out, if even one's undeniable beliefs may be false, it is doubtful that one could have much warrant in believing one's other beliefs to be true. ${ }^{24}$ The reason for this is that these other beliefs (at least implicitly) rely on the transcendentally necessary ones, as those express "certain ways in which we must think if thought and experience are to be possible at all." (Stroud 1977, 106) Now if the conditions for the possibility of "thought and experience" do not obtain, then whatever we think or experience, we have no way to know whether or how those relate to reality. Curiously, however, Bosserman's answer to the Stroudian critique can itself be subjected to the Stroudian critique, since, as we have pointed out earlier, it only shows-granting that it succeeds - that ST is self-stultifying. The burden, then, is still on Bosserman to show how this implies that ST is false-otherwise, he cannot claim that the weak (C1) can be known to be true by the skeptic. Given this shortcoming, Bosserman does not succeed in showing the falsehood of ST but rather illustrates the difficulty in overcoming the objection.

A second attempt to answer Stroud in a similar vein is found in Gabriel Fluhrer's 2015 dissertation, chapter three: "Presupposition and Transcendental Argument: Analysis and Critique of Non-Christian Conceptions." Fluhrer's lengthy treatment consists mainly of two parts. First, a survey of contemporary analytic philosophers'-mainly Robert Stern's and Barry Stroud's - treatments of TAs with special attention to the distinction between modest and ambitious TAs, and their dismissal of the latter. Second, an argument that the Stroudian construction of TAs rests on presuppositions which contradict $\mathrm{CT}$, and thus that the Stroudian objection begs the question against TACT. (Fluhrer 2015, 95-137) Fluhrer's analysis of Stroud's implicit presuppositions is aptly summarized in the following passage of his:

As we saw in the modal discussion above, analytic philosophers in general (and Stroud in particular) operate from an empiricist epistemology, which, with the assistance of materialist science, supposedly eschews metaphysics altogether. But even this strict empiricism assumes some very definite metaphysical truths. To name just a few: the existence of a mindindependent world (contrary to Stroud's claims), abstract laws of logic which govern laws of syntax in communication, the existence of other minds, and the non-existence of the ontological Trinity. Accordingly, Stroud, following modem philosophy, has smuggled in metaphysical

24 This consequence seems to-at least to some degree-depend on the probabilities of transcendentally necessary propositions turning out to be false. However, due to the very nature of these propositions, it would be quite difficult, or rather next to impossible to assess these probabilities without assuming the propositions to be true. (Cf. Stroud 1977, 106) 
assumptions, showing that he is not a neutral metaphysical bystander.

$(120-121)$

He then goes on to argue that these metaphysical assumptions entail some sort of skepticism (121-122, see more on this later). Therefore, if one were to utilize Stroud's analysis of TAs as a critique against TACT, he would both be begging the question and assuming a position which entails skepticism.

The main problem with Fluhrer's treatment here is that he does not argue his assertions about Stroud's presuppositions properly. We find in his dissertation no direct analysis of Stroud's arguments where the implicit premises or commitments are pointed out. What we do find is a historical survey of analytic philosophy, where his argument basically is that the first proponents thereof, G. E. Moore and Rudolf Carnap, were committed to materialism (102) and that no one since them (including Kripke, van Inwagen, and Plantinga) has adequately revised their approach to metaphysics and modality. These assertions, however, are not substantiated by careful analysis and seem far too radical to be accepted on the basis of a few examples. What is more, there is reason to think that recent trends in analytic philosophy do not adhere to the anti-metaphysical stance of their predecessors. As Timothy Williamson writes: "Despite that history, however, recent decades have seen the growth and flourishing of boldly speculative metaphysics within the analytic tradition." (Williamson 2014, 7)

He concludes a section of his treatment of Stroud by stating that "contemporary philosophical constructions of transcendental arguments, as exemplified by Stroud, end in global skepticism." (126). This, however, should not be surprising, since Stroud concedes that radical skepticism cannot be refuted (thus his position, when pushed, can "end in" it), and Fluhrer acknowledges his doing so. (118) However, pointing this out is not an adequate response from Fluhrer (though he seems to think that it is), since he claims that "Van Til thought that a sound and specifically Christian transcendental argument would refute even the radical skeptic," (100, emphasis original), and his goal is to reconstruct and defend Van Til's argument.

Ultimately we can discern two (complementary) lines of reasoning in Fluhrer's treatment. On the one hand, he argues that presenting ST as an objection against TACT begs the question because CT denies ST. However, since TACT seeks to be a persuasive anti-skeptical argument, the skeptic has to be shown that ST is false if TACT is to succeed-pointing out that it (allegedly) contradicts CT does not achieve what a TA is expected to achieve. On the other hand, he argues that ST is closely linked to metaphysical considerations which somehow lead to skepticism-so, presumably, it cannot be rational to hold to ST. This is a claim very similar to what Bosserman makes, that ST is self-stultifying-and the same objection applies to Fluhrer's argument which we have presented contra Bosserman: even if he is right, the falsity of ST does not follow per se, and therefore (C1) cannot be taken to be established as true. As we can see, while Fluhrer's case falls into the category of the 
objection-undermining strategy, neither line of his argumentation succeeds in demonstrating the weaker first premise of TACT.

In the evaluation of the objection-undermining strategy, we should consider it generally as well, apart from the specific formulations in the literature. Does it have any additional potential or merit? We can define this approach as an attempt to in some sense undermine ST in a transcendental way. However, this "undermining" would have to be so strong as to demonstrate that ST is actually false and so its negation is true. It may be helpful to think about what that negation precisely is, which I shall call the minimal idealism thesis:

(MIT): Self-stultification implies falsehood.

The reason I identify this thesis as minimally idealist is that, as we have discussed in the introduction, most see verificationism and idealism as the two metaphysical views on which an ambitious transcendental argument can succeed; and the reason for this is plausibly their denial of ST, which just is the affirmation of MIT. Accordingly, the thesis could be called minimal verificationism thesis just as well.

If we were to claim that the objection-undermining strategy can succeed in undermining ST to the extent that it is shown to be false, we would be making a claim to an ambitious TA for MIT. (In these terms, we can see that Bosserman's and Fluhrer's responses failed because they only produced modest TAs for it.) I do not know what that argument would look like or how it would proceed, but for the sake of argument, let us assume that formulating such an argument is possible; that is, that it could be shown that ST is performatively self-falsifying. The entirety of TACT would thus consist of a modest TA for CT in conjunction with an ambitious TA for MIT. Now, a proposition can relate to a set of propositions in three ways in principle: it can be inconsistent with the set; it can be unrelated to the set, that is, both its truth and its falsity could be consistent with the set; or it could be included in or implied by the set. I will argue-in this order - that whichever the relationship between MIT and CT is, defining TACT as an ambitious TA for MIT "plus" a modest TA for CT (minus MIT) is problematic.

First, if one takes MIT to be inconsistent with $\mathrm{CT},{ }^{25}$ this is evident, since the conjunction of the two arguments would result in a contradiction. Second, for a proponent of TACT who believes that both ST and MIT are consistent with CT, this

${ }^{25}$ As does Riley, apparently: "The kind of idealism that would allow us to draw conclusions about the way things must be from the way that we must think is the kind of idealism that is utterly committed to an unbiblical conception of human autonomy. ... Because creaturely idealism (that reality is somehow determined by the creatures' minds) is utterly incompatible with Reformed Christianity, it is in no sense the answer to the Stroudian problem for Van Til." (Riley 2014, 263, emphasis original) Note, however, his assumption that MIT is inextricably linked to the metaphysical notion that mind determines matter, while it is actually sufficient to hold something like that mind corresponds to matter. (One might start to wonder why this paper includes no analysis of Riley's response to Stroud, given that I make so much use of his dissertation written on this very topic-the reason is that I could not discern what his proposed solution was!) 
would mean that a thesis that is neutral with respect to CT has to be agreed upon by the (former) skeptic and the proponent of TACT so that on that basis CT could be established. This, however, contradicts the Van Tillian principles espoused by most supporters of TACT - for, according to Van Til, one ought not "appeal to 'common notions' which Christian and non-Christian agree on" when making an argument for CT. (Van Til 1971, 21; cf. Bahnsen 2011, 34-35) Moreover, if the proponent of TACT believes that these principles are implied by CT itself, as Van Til and many of his disciples do, then construing TACT with the structure currently under discussion would be inconsistent with what it seeks to establish, like proving with a modus ponens that modus ponens is an invalid argument form.

Third, suppose that a proponent of TACT believes that MIT is entailed in, or at least plausibly implied by CT. ${ }^{26}$ This gives a certain queerness to the structure of TACT, even if we are entirely optimistic as to its potential success: why should we think that while most of CT can only be established with a modest TA, one specific tenet of it, MIT, can be established in an ambitious way? This is a strange construal indeed, especially for those who support and seek to establish a form of TACT for theological reasons. Concluding my analysis of this trilemma, it seems to me that even if one grants that an ambitious TA for MIT is possible (which most of us do not find much reason to do), formulating TACT and saving it from the Stroudian critique along the lines of the objection-undermining strategy is deeply problematic.

\section{Conclusion}

In conclusion, let us take a look at what has been established and what routes could be taken by the proponent of TACT. We have seen that if one seeks to formulate a TA for the truth of $\mathrm{CT}$, one has to be able to offer a satisfying answer to the Stroudian critique. We have also seen that multiple proponents of TACT have attempted to do so, in primarily two ways: what I called the Biblical justification strategy and the objection-undermining strategy. We have seen, I believe, that the specific instances of these responses are inadequate, and that these approaches, in general, face debilitating deficiencies. What options are available then to the proponent of TACT?

I see three ways in principle to offer a satisfactory answer to Stroud given what I have previously said in this paper. One is to reject my formulation of TACT as flawed to the degree that my criticisms based on it are not relevant to TACT properly understood, and then show how an ambitious TACT could proceed. Another is to establish $\left(\mathrm{C}^{\prime}\right)$ in a way that is persuasive to the skeptic-a strategy I called

\footnotetext{
${ }^{26}$ Fluhrer, as we saw earlier, probably takes this position. Also, John M. Frame argues: "If a belief 'must be held,' then it must be true. Why? Because 'must be held' designates a moral obligation, and moral obligation is always established by God. If God says we have an obligation to believe $p$, then $p$ must be true, since God never requires us to believe falsehood." Personal e-mail correspondence, 2015. 05. 16., emphasis added. Quoted with his permission. Frame develops his idea that logic is a subset of ethics and therefore logical laws and obligations are moral laws and obligations in various places in his writings (e.g. Frame 2015a, 98-124; 2015b, 13-14, 33-36; cf. Riley 2014, 197-200).
} 


\section{BÁLINT BÉKEFI}

"strengthening the second premise". Though I have argued that the Biblical justification strategy is untenable, it is only one of possibly multiple ways to establish $\left(\mathrm{C}^{\prime}\right)$. The last is to show that ST is analytically false or performatively self-falsifying and that MIT is implied by or entailed in CT, which would be the strongest form of the objection-undermining strategy, and would demonstrate the truth of (C1). Is it possible to vindicate TACT in any of these ways? If my concluding new objection to TACT based on some characteristics of CT is right, then to that we have to answer "it is not". Consider the following argument:

(6) If TACT is sound, then CT can be known without an appeal to perceptual knowledge. (premise)

(7) According to CT, at least some parts of CT can be known only through an appeal to divine special revelation. (premise)

(8) An appeal to divine special revelation inevitably includes some appeal to perceptual knowledge. (premise)

(9) Therefore, according to CT, at least some parts of CT cannot be known without any appeal to perceptual knowledge. (From 7-8)

(10) There, according to CT, TACT is not sound. (From 6, 9)

(11) If TACT is sound, then CT is true. (From C1 or C1')

(12) Therefore, TACT is not sound. (From 10, 11) ${ }^{27}$

Premise (6) clearly follows from (C1) or (C1') if we see that neither self-stultification nor performative self-falsification entails any appeal to perceptual knowledge-and it should not if it seeks to answer the skeptic. ${ }^{28}$ Premise (8) is also clear if we understand special divine revelation to have happened in history: through the teachings of Jesus and the apostles, or through the inspiration of the Bible, for example. I take it that the only controversial premise here is (7). However, it finds clear support in the writings of Van Til (and other Reformed theologians, cf. Barrick 2004): he even seems to claim that divine special revelation is necessary not only to demonstrate or establish but even to properly understand Christian doctrine:

Even in paradise, Adam had to regard all the facts of his natural environment in the light of the goal that God set for man in his supernatural revelation. ... It is therefore not to depreciate natural revelation to say that it must, to be understood aright, be seen in terms of the system of truth revealed in Scripture. (Van Til 2008, 205; cf. Baird 2015, 87-91)

${ }^{27}$ If $\mathrm{A}$ implies $\mathrm{B}$, and B implies not $\mathrm{A}$, then $\mathrm{A}$ implies not $\mathrm{A}$, so A is false.

${ }^{28}$ One might claim that maybe TACT is sound but it cannot be known to be sound - that would mean that (6) is false. This, however, is inconsistent with the Van Tillian principle that CT can be demonstrated through TACT. 
Or, to quote one of Van Til's primary theological influences, Herman Bavinck: "General revelation leads to special, special revelation points back to general. The one calls for the other, and without it remains imperfect and unintelligible." (Bavinck 1909, 28, emphasis mine) Consider also one of Van Til's most prominent Princeton professors and colleagues, B. B. Warfield:

\begin{abstract}
We must conceive of special revelation, and of the Scriptures as just its documentation, therefore, as not precisely a cure, but rather an assistance to man dulled in his sight so as not to be able to perceive God in His general revelation. ... The function of Scripture thus, as special revelation documented, is to serve as spiritual spectacles... they reveal also the God of Grace, who may not be found in nature... without the "spectacles" of Scripture, sinful man would not be able to attain to a sound knowledge of even God the Creator. (Warfield 1909, 259-60, emphasis mine)
\end{abstract}

We see then that the Van Tillian proponent of TACT claims both the indispensability of special divine revelation (i.e. the Christian Scriptures) for the understanding of Christian truth, and the sufficiency of transcendental argumentation to demonstrate the truth of CT. This inconsistency, in conjunction with the grave problems TACT faces with respect to the Stroudian critique, by my reckoning, render TACT an argument that can quite safely be called unsuccessful. ${ }^{29}$

\title{
Bibliography
}

Anderson, James N. 2005. "If Knowledge Then God: The Epistemological Theistic Arguments of Plantinga and Van Til." Calvin Theological Journal 40: 49-75.

Anderson, James N. 2011. "No Dilemma for the Proponent of the Transcendental Argument: A Response to David Reiter." Philosophia Christi 13 (1): 189-98.

Bahnsen, Greg L. 1998. Van Til's Apologetic: Readings and Analysis. Phillipsburg, NJ: P\&R Publishing.

Bahnsen, Greg L. 2011. Always Ready: Directions for Defending the Faith. Edited by Robert R Booth. Digital edition. Nacogdoches, TX: Covenant Media Press.

Baird, James Douglas. 2015. “Analogical Knowledge: A Systematic Interpretation of Cornelius Van Til's Theological Epistemology." Mid-America Journal of Theology 26 (3): 77-103.

Bardon, Adrian. 2005. "Performative Transcendental Arguments." Philosophia 33: 6995.

Barrick, William D. 2004. “The Necessity of Scripture." The Master's Seminary Journal 15 (2): 151-64.

Bavinck, Herman. 1909. The Philosophy of Revelation. New York, NY: Longmans,

${ }^{29}$ I would like to thank Brian Knapp and Scott Terry for inspiring discussions on the subject matter of this paper; Ronald DiGiacomo and the three anonymous reviewers for their comments on previous drafts of this paper; and Howard Robinson, James Anderson, and Michael Riley for both. 
Green, and Co.

Berkhof, Louis. 1996. Systematic Theology. Grand Rapids, MI: Eerdmans.

Bosserman, Brant A. 2014. The Trinity and the Vindication of Christian Paradox. Eugene, OR: Wipf and Stock.

Bradford, Aaron. 2004. "Transcendental Arguments: Critique of Barry Stroud's Treatment." Master's thesis, California State University.

Brueckner, Anthony L. 1983. “Transcendental Arguments I." Noûs 17 (4): 551-75.

Brueckner, Anthony L. 1996. "Modest Transcendental Arguments." Philosophical Perspectives 10: 265-80.

Butler, Michael R. 2002. “The Transcendental Argument for God's Existence." In The Standard Bearer: A Festschrift for Greg L. Bahnsen, edited by Steven M. Schlissel, 65124. Nacogdoches, TX: Covenant Media Press.

Cassam, Quassim. 2003. "Self-Directed Transcendental Arguments." In Transcendental Arguments: Problems and Prospects, edited by Robert Stern, 83-110. New York, NY: Clarendon Press.

Collett, Don. 2009. "Van Til and Transcendental Argument Revisited." In Speaking the Truth in Love: The Theology of John M. Frame, edited by John J. Hughes, 460-88. Phillipsburg, NJ: P\&R Publishing. $\quad$ http://www.tsm.edu/wpcontent/uploads/Collett - Van Til and Transcendental Argument Revisited.pdf.

Page numbers refer to the linked PDF version. (Last accessed on 2017. 09. 04.)

Crisp, Thomas M. 2009. “On Believing That the Scriptures Are Divinely Inspired." In Analytic Theology: New Essays in the Philosophy of Theology, edited by Oliver D. Crisp and Michael C. Rea, 187-213. New York: Oxford University Press.

Dennison, William D. 2015. In Defense of the Eschaton: Essays in Reformed Apologetics. Edited by James Douglas Baird. Eugene, OR: Wipf and Stock.

Fluhrer, Gabriel Nourse Emil. 2015. “'Reasoning by Presupposition': Clarifying and Applying the Center of Van Til's Apologetic." PhD diss., Westminster Theological Seminary.

Förster, Eckart. 1989. "How Are Transcendental Arguments Possible?" In Reading Kant: New Perspectives on Transcendental Arguments and Critical Philosophy, edited by Eva Schaper and Wilhelm Vossenkuhl, 3-20. Oxford: Blackwell.

Frame, John M. 1995. Cornelius Van Til: An Analysis of His Thought. Phillipsburg, NJ: P\&R Publishing.

Frame, John M. 2015a. A History of Western Philosophy and Theology. Phillipsburg, NJ: P\&R Publishing.

Frame, John M. 2015b. Apologetics: A Justification of Christian Belief. Edited by Joseph R Torres. Phillipsburg, NJ: P\&R Publishing.

Grayling, A C. 1985. The Refutation of Skepticism. La Salle, IL: Open Court Publishing. McConnel, Timothy I. 2005. "The Influence of Idealism on the Apologetics of Cornelius Van Til." Journal of the Evangelical Theological Society 48 (3): 557-88.

Morley, Brian K. 2015. Mapping Apologetics: Comparing Contemporary Approaches. Downers Grove, IL: InterVarsity Press.

Oliphint, K. Scott. 2011. God with Us: Divine Condescension and the Attributes of God. 
Wheaton, IL: Crossway.

Oliphint, K. Scott. 2013. Covenantal Apologetics: Principles and Practice in Defense of Our Faith. Wheaton, IL: Crossway.

Oliphint, K. Scott. 2015. “Gauch's 'Gotchas': Protestant Principia and the Problem with Public Presuppositions." Philosophia Christi 17 (2): 443-56.

Oliphint, K. Scott. 2016. "Covenant Model." In Four Views on Christianity and Philosophy, edited by Paul M. Gould and Richard Brian Davis, 71-98. Grand Rapids, MI: Zondervan.

Plantinga, Alvin. 2000. Warranted Christian Belief. New York, NY: Oxford University Press.

Reiter, David. 2011. “The Modal Transcendental Argument for God's Existence.” The Confessional Presbyterian 7: 3-8, 298.

Riley, Michael P. 2014. “Barry Stroud's Argument Against World-Directed Transcendental Arguments and Its Implications for the Apologetics of Cornelius Van Til." PhD diss., Westminster Theological Seminary.

Rorty, Richard. 1971. "Verificationism and Transcendental Arguments." Noûs 5 (1): 3-14.

Shannon, Nathan D. 2012. "Christianity And Evidentialism: Van Til And Locke On Facts And Evidence." Westminster Theological Journal 74 (2): 323-53.

Sims, Bryan B. 2006. "Evangelical Worldview Analysis: A Critical Assessment and Proposal." PhD diss., Southern Baptist Theological Seminary.

Skidmore, James. 2002. "Skepticism about Practical Reason: Transcendental Arguments and Their Limits." Philosophical Studies 109 (2): 121-41.

Stern, Robert. 2003. "Introduction." In Transcendental Arguments: Problems and Prospects, edited by Robert Stern, 1-12. New York, NY: Clarendon Press.

Stern, Robert. 2007. "Transcendental Arguments: A Plea for Modesty." Grazer Philosophische Studien 74: 143-61.

Stern, Robert. 2017. "Transcendental Arguments." The Stanford Encyclopedia of Philosophy. $\quad$ https://plato.stanford.edu/archives/sum2017/entries/transcendentalarguments/. (Last accessed on 2017. 09. 05.)

Stroud, Barry. 1968. "Transcendental Arguments." The Journal of Philosophy 65 (9): 241-56.

Stroud, Barry. 1977. “Transcendental Arguments and 'Epistemological Naturalism.'” Philosophical Studies 31 (2): 105-15.

Sutanto, Nathaniel Gray. 2016. "Two Theological Accounts of Logic: Theistic Conceptual Realism and a Reformed Archetype-Ectype Model." International Journal for Philosophy of Religion 79 (3): 239-60.

Thomson, Judith Jarvis. 1964. "Private Languages." American Philosophical Quarterly 1 (1): 20-31.

Tipton, Lane G. 2004. “The Triune Personal God: Trinitarian Theology in the Thought of Cornelius Van Til." PhD diss., Westminster Theological Seminary.

Van Asselt, Willem J. 2002. "The Fundamental Meaning of Theology: Archetypal and Ectypal Theology in Seventeenth-Century Reformed Thought." Westminster 


\section{BÁLINT BÉKEFI}

Theological Journal 64 (2): 319-35.

van Fraassen, Bas C. 1968. "Presupposition, Implication, and Self-Reference." Journal of Philosophy 65 (5): 136-52.

Van Til, Cornelius. 1971. "My Credo." In Jerusalem and Athens: Critical Discussions on the Philosophy and Theology of Cornelius Van Til, edited by E. R. Geehan. Phillipsburg, NJ: P\&R Publishing.

Van Til, Cornelius. 2003. Christian Apologetics. Edited by William Edgar. $2^{\text {nd }}$ ed. Phillipsburg, NJ: P\&R Publishing.

Van Til, Cornelius. 2008. The Defense of the Faith. Edited by K. Scott Oliphint. $4^{\text {th }}$ ed. Phillipsburg, NJ: P\&R Publishing.

Warfield, Benjamin B. 1909. "Calvin's Doctrine of the Knowledge of God." The Princeton Theological Review VII: 219-325.

Williamson, Timothy. 2014. "How Did We Get Here from There? The Transformation of Analytic Philosophy." Belgrade Philosophical Annual 27: 7-37. 